\title{
Islam and Prejudice: Special Reference to Gordon W. Allport's Contact Hypothesis
}

\author{
*BENAOUDA BENSAID ${ }^{1}$ \\ MUSTAFA TEKKE ${ }^{2}$ \\ ${ }^{1}$ Department of General Education, College of Science and Humanities, \\ Effat University, Jeddah, Saudi Arabia \\ ${ }^{2}$ Department of Psychological Counseling and Guidance, Düzce University, Düzce, Turkey \\ *Corresponding author: bbensaid@effatuniversity.edu.sa
}

Published date: 20 December 2018

To cite this article: Bensaid, B. and Tekke, M. 2018. Islam and prejudice: Special reference to Gordon W. Allport's contact hypothesis. KEMANUSIAAN the Asian Journal of Humanities 25(Supp. 1): 103-120, https://doi.org/10.21315/kajh2018.25.s1.6

To link to this article: https://doi.org/10.21315/kajh2018.25.s1.6

\begin{abstract}
This study explores the Muslim perspective on human interaction, relationships and prejudice. A survey of the literature recognises Islam's fundamental acknowledgement of human diversity, drawing on a dynamic theological, moral, spiritual and legal philosophy revolving around the preservation and sustainment of non-prejudiced human contact. This study discusses the Muslim perspective of human contact, non-prejudice, and accordingly, revisits Gordon W. Allport's "Theory of Contact Hypothesis" in an effort to compare and contrast it with the Muslim perspective on related issues such as racial prejudice, gender inequity, age prejudice, disability discrimination, social status and classism. This research concludes that Islam has developed a framework necessary for cultivating religiosity and morality without risking the value of effective and harmonious human relations. Further empirical studies on the interplay between Muslim theory and practice on contact hypothesis and prejudice are required to further interpret the dynamics of Muslim values in working settings, and the viability of translating religious ideals into reality.
\end{abstract}

Keywords and phrases: contact hypothesis, Gordon W. Allport, Islam, prejudice, racism

\section{Introduction}

Prejudice can be described as the unfair and rigid judgment about others. According to Woolfolk, prejudice is constituted of beliefs, emotions and tendencies towards particular actions $(2016,251)$. This cognition initiates from childhood in the form of schemas, evolving as stereotypes in such patterns of belief against a group of people throughout a lifespan. Research on the connection between prejudice and religion began with early studies of Adoree and his colleagues in the late 
1940s (Hood Jr., Hill and Spilka 2009) and continues to support similar findings (Rowatt, Carpenter and Haggard 2014). The conceptualisation and measurement of religious orientation however, began with Allport and Ross (1967) and continued with Gorsuch and McPherson (1989) in the context of prejudice. Allport is recognised as the founder of the cognitive approach of prejudice (Dovidio, Glick and Rudman 2005) over discussions on the nature of prejudice in the field of religious fundamentalism. Allport views prejudice as a negative feeling or attitude, a failure of rationality (Allport 1966, 448) and a stereotyped overgeneralisation (Allport and Ross 1967, 412). In a religious context of prejudice, Allport sought to investigate the varying degrees of prejudiced belief of church attendants and nonattendants, both on the theoretical and empirical level. According to him, church non-attendants exhibit less prejudice than church attendees.

Allport (1966) believes that communal and extrinsic religion become particularly imperative in the context of theological prejudice. For him, religious orientation of extrinsic and intrinsic motivation which represents a "subjective formation within personal life" (Allport 1966,456), and sheds light on the varying degrees of prejudice among church groups; though the extrinsic and intrinsic conceptualisation was revised to adapt a better understanding of religion (Gorsuch and McPherson 1989). For instance, church attendance was perceived as an intrinsic rather than extrinsic orientation. Interestingly, the findings of both Allport and Ross (1967) indicate that the intrinsically religious are less prejudiced than their extrinsic counterparts, ${ }^{1}$ implying that the extrinsic orientation draws on a strong support of intolerance and bigotry whereas the intrinsic orientation favours tolerance. Moreover, an extrinsic religious orientation is found to be compatible with prejudice whereas the intrinsic orientation supports tolerance and humanitarianism. More particularly, the extrinsic orientation focuses on the outlook of religion rather than perceiving the meaning of religion per se and hence is perceived as a weak superficial act, subject to easily changed belief (Allport 1966).

Five decades following Allport's research, the theological context of prejudice remains intriguing whereas interesting findings remain beyond the idea of communal and extrinsic religion seen as a cause of bigotry. In their work, The Psychology of Religion: An Empirical Approach, Hood Jr., Hill and Spilka (2009) presented a broad perspective of religion and prejudice according to which religious orientation should be reflected through a comprehensive meaning of culture, society and other relevant factors. Interaction and contact with other cultural and social systems need to be examined in an objective evaluation of the relationship of religion vis-à-vis prejudice (Ghorbani et al. 2002). Since major religious traditions support or motivate their adherents to love one another, thus resulting in reduced prejudice, religion again plays an important role in the mechanism of orienting systems of perception and engagement with others at large (Randolph-Seng 2014). 
Allport's proposal on contacthypothesis is regarded as instrumental to understanding the religion-prejudice relationship. According to the contact hypothesis, positive attitudes increase when contact between group's increases, while prejudice may reduce among opposite groups through out-group contact under optimal conditions (Allport 1954). This hypothesis demonstrates that the understanding of religious tradition is critical not only to the clarification of the role of group contact, but also in regards to the position of religious beliefs, spirituality, morality and laws concerning the philosophy and quality of intergroup contacts. As such, this study seeks to explore the Islamic perspective on group contact with special reference to Allport's hypothesis in view of the assumption that religious approaches to prejudice may offer insightful understanding leading to an enriched understanding of human contact and inter-group interactions. More specifically, the exploration of the Islamic insight on intergroup contacts is useful in view of the rising degrees of tension, conflict and prevalent marginalisation of religious communities in the present day. The Islamic perspective remains significant, with respect to not only understanding the other, but also in view of incorporating diverse global religious and native perspectives, and capitalising on Islamic values and principles towards engineering realistic, effective and more inclusive approaches to the study of human intergroup contact. This study seeks to explore the relevant religious Muslim texts to gain an understanding of the normative religious notions that define Muslims' perception of others and how adherence to the Islamic religion shapes its followers' attitudes towards prejudice, or threatens out-groups.

\section{Islamic Perspective on Human Contact}

This section discusses the Islamic perspective on human contact and highlights the underlying factors affecting Muslims' interpersonal and intrapersonal perceptions, relations and rapprochement. The understanding of the theological and religious premises vis-à-vis the human contact theory is critical to appreciating the nature of Muslims' engagement in cross-cultural and inter-communities' interactions, while detecting concepts that may infiltrate the web of Muslim beliefs and thoughts. The methodology in this study is primarily one of textual analysis and hence normative. First, one finds that the Qur'anic view on human relations is imbued with the theological foundation of the unity of creation and the principle that humans are children of Adam, and that none are entitled to privileged treatment over others. As such, there is no effectual value assigned to human characteristics such as race, colour, gender, age, language, social status, physical appearances and the like. It is with this view that the Qur'an exhorts its followers to initiate spaces for dialogue, interaction and courtesy. ${ }^{2}$ Muslim sources discuss unity, sameness of human race, and further underscore the imperative for activating spirituality and religiosity to preserve the moral quality compass. Moreover, while they hold 
belief in human sameness, they appear to resist all perceptions of assigned human characteristics or attributes, maneuvered racial or socio-economic differences, and instead acknowledge good contributions to life alongside a profound appreciation of qualities of knowledge, character and righteousness. Sameness therefore implies a reference to the original creation, reflecting the equality of human species before God, and the rejection of all forms of distortive representations of human contact such as humiliation, exclusion, abuse, exploitation, control, manipulation, sacrifice or exaltation.

Among the renowned Islamic religious directives in this regards is a prophetic declaration that people are as equal as the teeth of a comb, bringing to mind the image of a human family line tracing back to the progenitor Adam, and further cautioning against prejudice, and racism which carries no self-merit. In addition to this concept is the principle that difference of skin colour holds no social implications, and that the pride of early Arabs in the pre-Islamic period towards clan and lineage is outright rejected. Many similar religious directives require Muslims to maintain courteous interactions with their co-religionists, give in charity with sincerity, treat neighbours with kindness, conduct business with trust and integrity, lend and borrow with justice, choose spouses without racial bias, treat employees, clients and customers justly and decently, avoid ridiculing and nicknaming or mocking others, and set equal social justice fairly (Qur'an 5:42).

Islam also revisits the concept of beauty and humanity, making it worthwhile to draw attention to its inner dimension, and setting the perception, evaluation, interaction and norms of human treatment accordingly. Such philosophy places less attention on colour, race, language, wealth, gender, physical strength, ancestry, traditions; and instead places emphasis on the universal criterion of character, piety and goodness. Drawing on the Qur'an's perspective, one finds use of the term ta 'aruf (knowing one another) which is derivative of ma'rifah (knowledge), and this places focused attention on the level of character building, cultivation of piety and self-discipline; all of which highlight Islam's prioritised interest of the inner human character and the intrinsic beauty of man as illustrated in numerous traditions of the Prophet Muhammad (pbuh). ${ }^{3}$ Setting human judgement in a rather vertical axis inclined towards divine satisfaction is perhaps purposeful towards molding human attitudes away from superficial or artificial considerations, and instead, around inner persuasions with effectively objective effects on their surroundings.

This theological perspective adds further value to the quality of human contact by way of drawing differences to their original circles, all without neglecting core humanistic values, and further reminds of the importance and often-neglected 
innate human dimension resulting from inattention to the spirituality of man. Interestingly, the Qur'an revisits the filters of race, colour and ethnicities, addressing them in light of the principles of unity of creation and the sameness of creation, with the purpose of eliminating accumulated judgments, biased assumptions, misperceptions and returning to the beginning of human contact. To this end, the tradition of Prophet Muhammad states:

All of you descend from Adam, and Adam was made of earth. There is no superiority for an Arab over a non-Arab nor for a non-Arab over an Arab, neither for a white man over a black man nor a black man over a white man. (Albani 1984, 361)

Along similar lines of thought, Islam is keen on developing Muslims' knowledge and familiarity of other communities and understanding their conditions, backgrounds and languages. This is likely set to nurture mutual acquaintances, drawing groups closer and eliminate human hazards. It is with such a view that Islam seeks to enrich intercommunity experiences and tolerance, promoting knowledge of the out-group, boosting community contact and further increasing empathy and perspective taking.

Prior to forging intercommunity contact, Islam seeks first to shape the ethical and spiritual in-group contacts, and as such mandates a basis of moral rectitude and established religious congregation as an effective arrangement for rapprochement so as to strengthen intergroups' contact while enhancing the ethical attributes of interconnectivity, integrity, tolerance and courtesy. As for intergroup contact in Islam, there exists a series of religious recommendations to consolidate the community's spiritual and social capital, and further enhance their effectual contact while increasing contact frequency and building on the resulting mutual discovery. This is represented for instance in the Muslim daily congregational prayers; mandatory Friday prayer; Eid prayers; Ramadan nightly prayers; funeral prayer; prayers of eclipse, rain, pressing need and so forth. In addition to the Five Articles of Islam, Islam also sets its ethical code of hygiene and public health, diet, business ethics, family management ethics, social solidarity, human relations and others to sustain an effective capital driving the vision of Muslim communities and ultimately their intergroup contacts.

The description discussed above should not suggest any ideal thesis of Muslim intergroup contact but rather anticipates humans to act upon their free will whilst exhibiting ordinary behaviour of compromise, conflict or reconciliation. This may also give reason as to why even in the presence of religious and spiritual discipline, human conditioning by way of education and law is critical in ensuring 
non-prejudiced intergroup contacts. In view of the above, however, there is a need to underscore Islam's keen interest in forging broader objectives for intergroup contact and exchange with a philosophy inherently imbued with the humanity, belonging to God and shared belief throughout the Adamic creation.

Alongside the significant interest in intergroup contact and fulfilling of groups' fundamental needs, Islam also introduces relevant intergroup principles best identified as the common ground (Qur'an 3:64), which in the context of religious intergroup contact, seeks to nurture interactive contacts leading to effective mutual familiarity, understanding and healthy intergroupness. The interest in common ground however, may turn disparaging with active prejudiced intergroup contact (Qur'an 30:22) in view of the fact that the commonality mindset opts for naturalised relations, compromising attitudes, mutual recognition and inclusive participation. Common ground engagement affects the intergroup contact, not necessarily via dissolving one's own religious beliefs or rituals, but rather, through the will to adopt differences, celebrate diversity, capitalise on shared human values of dignity, equality and humility, collective negotiation of the religious space, and deepening consciousness in regards to a "civilised" cross-religious unity. At the most generic level however, this should translate into a serious interest in education, interaction, communication, consolidation of power against humans, and social and environmental problems while constantly transforming spiritual inputs into constants of goodness and pity.

In addition, and congruent with the Islamic logic of human contact, one notes that in Islam there surges a profound yet compelling exhortation to assist others indiscriminately and unconditionally, while continuing to validate one's religiosity and spirituality by way of service, assistance and sympathy. The Qur'an is replete with exhortations to such meanings and virtues, as in the case with verse 5:2 which exhorts believers to cooperate on righteousness, and deeds that are beloved to God, whether related to individuals or groups. Religiosity is thus placed in the framework of freeing the self from egoistic self-centeredness and the actively passionate giving to others. However, what appears to be critical in the context of discussion at hand is that such a religious perspective also implies borderless resourcefulness, conditioned neither by belief nor by race, but rather applied to all openly. It is with this philosophy that Islam stresses not only furthering intergroups' contact but more importantly raising the quality of the contact itself. Resourcefulness transcends the colourful lenses of ideological, cultural or socioeconomic assumptions. Islam appreciates other groups, recognises their needs, and hence views marginalisation, human indifference and exploitation as a grave fault. To further protect the spiritual, moral and social capital of the community, it sets preservation of belief, life, intellect, human progeny, property, honour and 
dignity, environment, justice, freedom and social-human relations as a higher ends for good life. Those Islamic ideals represent the kernels of community building which bonds members to common living principles as they seek to nurture and sustain common interests in belief, health, life, intellect, wealth, freedom, justice, environment, and safeguard effective intergroup contacts, resulting in sustainable levels of interaction and exchange.

According to the Islamic viewpoint, these ideals are reflective of the innate human predisposition, intellect, human experience and revelation which seeks to ease life, sustain comfort and to avoid pain, escape inconvenience and harm, and add value to life, health, wealth, intellect, human lineage, freedom, justice, human relations and the environment, while improving and safeguarding those ideals and sustaining happiness. In this regard, rationality of religion posits that for sustainable living, people need to uncheck all barriers and prejudices that may jeopardise their shared interests, and set laws for life that ensure human interconnectivity. The legislation of the common interest is advantageous not only to the well-being of the community, but also to capitalising on human needs, aspirations and the desire to enjoy decent degrees of dignity and justice.

\section{Islam and Non-Prejudice}

In light of its integrative nature, Islam lays out an ethical and social order, resonating with innate human predisposition, intellect and community aesthetic. This, for instance includes the obligation of extending a helping hand to the less fortunate, giving in charity, caring for one's neighbours, ${ }^{4}$ mentoring and guiding others, sharing sustenance and open door homes, ${ }^{5}$ engaging in business with others, lending money, showing leniency, acting with trust and forgiveness, visiting the sick, attending funerals, and avoiding abuse and exploitation of others. Islam is also concerned with developing amiable interpersonal interactions, and as such, dictates rules prohibiting mockery, nicknaming, backbiting, gossiping, looking down upon others, thinking ill of others, and foregoing malicious, divisive and harmful speech. ${ }^{6}$

Similarly, it exhorts its adherents to demonstrate integrity, nobility, trust, confidentiality, decency and justice, even in cases of extreme enmity, ${ }^{7}$ to avoid disrespectful argumentation, or to insult others' faiths. Moreover, Muslim sources confirm a strong commitment to the community aesthetic, taste and the need for an atmosphere conducive to the enhancement, comfort and consolidation of intergroups contact. Chief among those expectations are hygiene, cleanliness, green conservation of environment, food diet, personal care, cheerfulness, adopting positive names, avoiding superstition and pessimism, ${ }^{8}$ personal grooming, ${ }^{9}$ 
public etiquette, animals care, avoiding witchcraft and magic, speaking gently, and walking humbly and decently. In the following section, we shall explore the objectives of Islam set to reduce prejudice in the context of the contact hypothesis.

First, the study of the principles of Islam points to a large interest in placing differences in the purview of diversity (Qur'an 109:6, 30:22), with an encouragement of mutual acquaintances (Qur'an 49:13) and of human equality, alongside exhortation on cooperation (Qur'an 2:5) and kindness for all (Qur'an 2:83). In Islam, human physical characteristics may constitute the person it qualifies as a unique being, but is nonetheless irrelative to the person's creaturely status before God. Such characteristics never determine ethical outcomes and are never conclusive, for it cannot be an axiom that a person with any imaginable combination of such characteristics is morally worthy or unworthy. The inner core is constitutive of the person's being and must therefore remain, to the extent required, free of those characteristics; both capable of using their determinative power as well as of doing otherwise, i.e., of channeling their causal efficacy to other ends (Abusulayman 1989, 46-47). As such, Islam holds that righteousness and its associates of goodness define one's self-image and value, thus rendering social status reflective of virtue, refined character and good contributions to others as shown in many religious traditions..$^{10}$ Islam also seeks to maintain equilibrium in human life while acknowledging human needs, passions and aspirations, which inevitably result in difference and distinction.

Interestingly, Islam does not appear to be in favour of disregarding human difference or demeaning people's earned merits, but instead preoccupied with disciplining the self and cherishing virtues of thankfulness, justice and compassion. For instance, Islam holds a high regard for work, ownership and earning, yet not according to an egalitarian basis of economy, ownership, living standards and merit. This leads to resistance against all forms of exploitation and degradation, preventing classification of recognition and merit according to gender, physical characteristics and other traits. Similarly, Islam censures the dissension of social classes and social conflicts in seeking social justice; but rather endeavours to build harmony through equality and justice as shown for example in its resistance against the monopoly of wealth and resources.

Second, the Islamic definition of gender falls within its broader Weltanschauung on the human creation and sameness, as seen in the definition of Muslim Revelation delineating the position, duties and responsibilities of both man and woman. The overwhelming majority of Islamic literature views man or women not according to their sexes and gender, but rather as the individual cumulative of humanness and accomplishments. According to Islam, gender alone does not 
grant special privileges or preference (Qur'an 4:19); piety and moral character however do, as shown in the following Qur'anic verse: "Whether male or female, whoever in faith does a good work for the sake of God will be granted a good life and rewarded with greater reward" (Qur'an 16:97, 33:35). The hadith tradition is replete with narrations on the principle of gender constructive partnerships, which is to be experienced with love, compassion and kindness (Qur'an 30:21). ${ }^{11}$

Along similar vein of thought and drawing upon the fundamental normative ethics of Islam on human equality, dignity and honour, the prodigious literature expounds on Islam's value for old age in granting a close bearing with God, thus providing it with theological and spiritual content. ${ }^{12}$ In his classic definition of ageism as "a process of systematic stereotyping of and discrimination against people because they are old" Robert Butler goes on to observe: "Old people are categorized as senile, rigid in thought and manner, old-fashioned in morality" $(1975,11)$. Ageism is often defined as prejudice and discrimination against older people based on age and includes for example denial of resources or opportunities, or viewing old age in negative stereotypes. The Islamic traditions give prominence to honoring old age, which further alludes to a distinct spiritual character of the elderly by means of distinguishing sanguine descriptions of grey hair taking the form of radiant light on the Day of Resurrection (Tirmidhi n.d., 3:224), and a sign of ascendancy of religious stature (Baghawi 1991, 6:211).

Islam maintains that age itself is neither demeaning nor an infirmity resulting in maltreatment, discrimination or prejudice. Islam acknowledges several weighty religious and spiritual dimensions corresponding old age with close acquaintance to the divine, acquisition of wisdom and elevated honour. As such, old age is not viewed as a burden but rather an avenue to a rewarding religious experience and drawing close to the divine. In fact, Muslim culture, which grooms its youth to show respect, defers to older people and further treats them with honour and dignity; in turn generating high social regard and respect for older individuals. ${ }^{13}$ Islam also establishes a number of spiritual, ethical and legal measures in ensuring just treatment and mercy showcasing essential values of dignity, honour, kindness, respect, appreciation, ease, support, solidarity and service (Bensaid and Grine 2014). All this is in addition to establishing justice over their rights and needs while guaranteeing an equitable distribution of responsibility in a manner that transcends religious, ethnic and cultural demarcations and discernment (Bensaid and Grine 2014).

In light of the above, one understands the spirit of Islam towards old age and elderly, and how it constitutes an ethical and legal system around dignity, respect, care and justice. Interestingly, those Islamic preventive norms transcend race, 
religions, classes and colour; alternatively revolving around the very essence of human creation, and as such, acknowledging inevitability of ageing along with its implicit occurring changes in physical appearance of the face, body, speech, mobility, cognitive abilities and emotional reactions. Moreover, Islam underscores the religious and moral duty of respect and care for elderly parents and the imperative to show them mercy and kindness in addition to safeguarding the financial rights of even non-parent elderly people. The sum and substance is that old age carries no demeaning association nor does it lower the image of the elderly in the community. Islam seeks to conjointly ensure a life of respect and dignity and to enrich the community's spiritual and moral culture high esteem for the elderly, in which they may oversee social functions, acting as witnesses to marriages, conflict, divorces, birth, social mediation or reconciliation.

Islam also advances its standpoint on people with disability which reflects profound theological persuasions reflective of the belief that true disability is that of the conscience and heart (Qur'an 22:46), and not of the body, in addition to viewing physical disability as rewardingly divine tests, ${ }^{14}$ in need for discipline of patience and thankfulness. Disability inspires the community to demonstrate thankfulness to God over their health and good shape, to show respect (Qur'an 49:11), console people with disability, ${ }^{15}$ socialise, share sustenance (Qur' an 24:61), accept their invitations, integrate them in society, ${ }^{16}$ pray for them, avoid deluding them, not show contempt, appreciate their qualities, join them in marriage, ease their inconveniences as well as remove their hardships (Qur'an 48:17). Physical changes may be irreversible and should be welcomed, and reacted to with utmost sensitivity, care and appreciation. In its place, it is believed that spiritual health, intellectual soundness, and social maturity would render age within a paradigm of natural prospects of change, and bring about the most humane and rational treatment of.

\section{Islam and Group-Norm Theory of Prejudice}

Allport's contact hypothesis states that the decline of prejudice directly corresponds to the amount and type of contact occurring between differing groups or cultures. The type of contact that mediates prejudice is the most influential aspect for initiating attitude and behavioural change. Allport sought to explain how the religious context instigates prejudice. In this, there exist mainly three categorisations of religious prejudice: the theological context, the socio-cultural context and the personal-psychological context (Allport 1966). Among those three categorisations, Allport draws attention to the context of intrinsic and extrinsic religious orientation of "person-psychological context". 
Allport (1954) further contends that interaction may lessen prejudice: (1) When those in contact are of equal status, (2) when those in contact perceive themselves to be in pursuit of common goals, (3) when contact is sanctioned by institutional support, the larger community or law, and (4) when the contact is positive in nature. Such interracial contact is most possibly apparent in diverse cultural societies (Schmid and Hewstone 2010). This contact could be evaluated again with a more specifically personal commitment and individual differences based on Allport's religious orientation. It appears that the findings of intrinsically motivated people exhibiting less prejudice implies that living the meaning of religion may in large part be advantageous to promoting equal status and cooperation, leading to common goals and institutional support with the implication that intrinsic orientations contribute significantly to intergroup relations. In Islam, belief in God and doing good (e.g., Tekke et al. 2016) are imperative for an understanding of intrinsic orientation, which could be a process of the personal-psychological context, expounded into relationships between commitment and religion. Therefore, good deeds are found here to affect the accountability of religious people to society (Tekke et al. 2015).

This social accountability helps maintain relationships with others as shown in Islam's interest to promote cooperation and intergroup relations through exhibiting resourcefulness to other groups. Good deeds, however, are not necessarily prerequisites for positive interaction towards out-group members seeing that religious groups, especially fundamentalists, are interested in the welfare of their members alone and not of out-groups (Theiss-Morse and Hibbing 2005). Therefore, it is argued that a prevalence of individual differences and negative attitudes might lead to prejudice (Whitley and Kite 2010), for the reason that one of the most frequent sources of prejudice is rooted in needs and habits that reflect the influence of in-group memberships upon the development of the individual personality. A member of a religious group associated with "fundamentalist" values may pose threats to other belief systems. Such prejudice is greatly associated with fundamentalist views, according to Allport $(1954,9)$, who asserted: "[prejudice] is actively resistant to all evidence that would unseat it".

In light of good deeds and social accountability, Gaertner and Dovidio (1986) enumerates the following postulates of Allport which he sees as necessary to increase intergroup cultural openness:

Interactions among members who do not possess qualities that are stereotypically associated with their group membership; situations that provide strong normative and institutional support for the contact; similarity of beliefs and values between groups; opportunity for intimate self-revelation, and personal contact. (318-319) 
According to Brown (1995), social and institutional support are measures employed to promote greater contact and interactions, existing to help create a social climate ripe for tolerant norms to emerge. According to Pettigrew and Tropp (2006), institutional support is a vital condition leading to the reduction of stereotypes and prejudice. Moreover, the contact between groups must be long enough, often enough and close enough for proximity to affect attitudinal change about different groups (Brown 1995).

Yet to help promote equality and cooperation among different groups, belief in God, social accountability, institutional support, individual difference and intrinsic motivation ought to be considered when carrying out good deeds (Ismail et al. 2016). Researchers like Batson and colleagues have revised Allport's conceptualisation of intrinsic orientation from belief and cognitive activities to social accountability and institutional support. The revised conceptualisation of religious orientation proposed by Gorsuch and McPherson (1989) factors in behaviour and religious attendance, often exploited by researchers. This understanding appears to be compatible with the Islamic perspective.

\section{Conclusion}

Despite the unwavering commitment of the Islam with its spiritual, moral-ethical, legal systems to cultivating and sustaining non-racial treatment of ethnicities, races and languages, and to eliminating all attitudes, practices and forms of ethnic prejudice and racism, the fact obviously points to continuing gap between theory and practice. This theoretical study does not intend to advance kind of utopic image of Muslim society free of all abuses, discriminations and racial practices. This is because Muslim society and culture continue to exhibit violations of those very norms and values, which in turn, could be caused by other complex factors including poor education, culturally bound religious textual interpretations, political maneuvering, sectarian interest manipulations, colonial exploitation, narrowed approach to change and so forth. One such present example is the notion underlying the privileged position of Arabic and Arabism, and in some instances, the related preference towards of Arabs over non-Arabs; this is despite the abundant textual evidences, which strongly call for abolishing all forms of linguistic preferences and rather insist on piety and righteousness as fundamental criterion.

Another related example is Islam's bold call for justice, kindness and courtesy towards other faith groups. The Islamic literature is replete with textual evidences underscoring the imperative to treat other faith groups with justice and fairness, and to act fairly, kindly and courtesy towards them. Dwelling on those texts would 
exceed the limits of this paper. Clearly, the theological teaching of Islam does not pose problem to the possible racial treatment or abuse of other faith groups. What appears to drive groups' behaviours is the problem of interpretation on the one part, and hence, there needs to be ongoing diagnosis of the forces underlying community dynamics. The religious and spiritual capital can certainly help remedy abnormal practices affecting human relations, however, to fully benefit from those capitals in the redefining and engineering of new web of relations and human interaction culture, one needs to re-evaluate the context and highlight the complex factors that directly and indirectly contribute to the shaping of current culture.

Nonetheless, through its integrated approach of the intrinsic and extrinsic values related to both in-group and out-group settings, Islam seeks to nurture individuals' and groups' resilience against prejudice and to sustain their immunity from discrimination. On the internal side, Islam deepens belief in individual accountability before God, accountability for one's acts of prejudice, and appreciation of dignity, equality, honorability of the human race. The translation of Muslim values and principles on sustained intergroups' non-prejudice is highly dependent on factors of education, engineered culture, methods and approaches of religious interpretation, styles of religious indoctrination and learned cultural stereotyping. Prejudice can be un-learned, and while spirituality goes hand in hand with learning, it invokes moral, ethical and legal commitment, in both the individual and public spheres to sustain the learning of non-prejudice. This process of un-learning prejudice and learning of non-prejudice can be characterised as profound, active, transparent and reflective in view of the very nature of the process and discipline of spirituality and religiosity in the life of the Muslim.

Nevertheless, it appears that the rediscovery of Islam's fundamental values of spirituality and religiosity could provide the framework necessary for shaping and at the same time nourishing much of Muslim's attitude, behaviour and feelings, and as such their interpersonal and intrapersonal relationships. This view continues to gain increased recognition in academia despite the ongoing problems of violence and terror allegedly associated to religion and to God. This current research has shed light on human contact, relationship and prejudice. Confirming Allport's contact hypothesis, Islam promotes such an environment of non-prejudiced to community to develop mutual understanding and co-existence. However, the suggestion of Muslim religious orientation of human contact, more particularly the intrinsic and extrinsic orientation, might be beneficial in spite of the present measure of religious orientation (Allport and Ross' religious orientation) being validated across a several countries. Muslim measures such as the "The Religiosity of Islam Scale" of Jana-Masri and Priester (2007) and "Hoge Intrinsic Religiosity Scale in Muslims" by Hafizi, Koenig and Khalifa (2015) help evaluate spirituality 
and religiosity, unfortunately they neglect the broad context of human contact in prejudice. Hence, the need for religious orientation measure to effectively assess Muslims' contact, relationships and prejudice and be used for further empirical measures.

\section{Notes}

1. The idea of extrinsic and intrinsic religious orientation by Allport (1950) was extensively discussed by researchers like Batson, Schoenrade and Ventis (1993), Benson (1988) and Poloutzian (1996).

2. The Qur'an states: "O mankind, We have created you from a male and a female and have made you into nations and tribes for you to know one another. Truly, the noblest of you with God is the most pious" (Qur'an 49:13).

3. Prophet Muhammad is reported to have said: "Allah does not look at your outward appearance and your goods. He looks only at your hearts and your deeds" (Qaysarani 1995, 1:599).

4. It is reported that a companion once asked the Prophet Muhammad: "Who is a neighbour?" He answered: "Your neighbours are forty houses ahead of you and forty houses to your back, and forty houses to your right and forty houses to your left" (Sakhawi 1993, 204). Prophet Muhammad is reported to have said:

He who closes his door from his neighbour in fear for his family and wealth is not a believer, and neither is he whose neighbour is unsafe from him a believer. Do you know the right of the neighbour? When in need of help, you support; when in need of a loan, you assist; when impoverished, you provide; when taken sick, you visit; when blessed with goodness, you wish well; when struck with calamity, you condole; when they pass on, you accompany their funeral.

If you have purchased fruit, then make a gift of it to your neighbour. If you have not done so, then take care to conceal it upon your return. Do not allow your child out with it, for it may embitter the neighbour's child or make them covetous. Do you know the right of the neighbour? By the one in whose hand is my soul, they who fulfill the rights of their neighbours do not exceed the few graced by Allah's mercy. He continued to advise them over neighbours, until they thought they would come to include them in their wills. (Bayhaqi 2003, 7:3136)

5. Prophet Muhammad is reported to have said: "The worst food is the food of a wedding banquet in which the rich are invited but the poor are left out" (Ibn al-Mulaqqin 2004, 8:10). The Bible also conveys similar meaning like: "But when you host a banquet, invite the poor, the crippled, the lame and the blind" (Luke 14:13). See Bible Hub retrieved from: http://biblehub.com/luke/14-13.htm (accessed 23 December 2016).

6. Prophet Muhammad is reported to have used the following supplication: "O Lord, I seek refuge with You from leading others astray, causing others to slip or being caused to slip by others, doing wrong or being wronged by others, or behaving foolishly or being treated foolishly by others". Sulayman $(1969,5094)$. 
7. In a famous decree, Abu Bakr al-Siddiq, the first Caliph, told his military commander:

Do not commit treachery or deviate from the right path. You must not mutilate dead bodies; do not kill a woman, a child, or an aged man; do not cut down fruitful trees; do not destroy inhabited areas; do not slaughter any of the enemies' sheep, cow or camel except for food; do not burn date palms, nor inundate them; do not embezzle (e.g., no misappropriation of booty or spoils of war) nor be guilty of cowardliness ... You are likely to pass by people who have devoted their lives to monastic services; leave them alone. (Ibn Kathir $1995,2: 320)$

8. Prophet Muhammad is reported to have said: "No contagion, no pessimism, no haammah [bird] and no Safar" (Albani n.d., 783). The pre-Islamic Arabs used to think that whenever this bird landed on anyone's house, somebody who lived in that house would definitely die. As for Safar is a worm which used to dwell in the bodies of some animals (as a disease) and that this disease was contagious.

9. Prophet Muhammad is reported to have said: "Five are from the natural practices: circumcision, shaving the pubic hair, cutting the moustache short, clipping the nails, and plucking the armpit hairs" (Bukhari 1980, 5889). Prophet Muhammad is reported to have also said: "Keeping your eyes down, clearing the streets of obstacles, responding to Salam greetings, enjoining virtuous deeds and forbidding evil" (Bukhari 1980, 2465). In another narration, he added: "Helping the aggrieved and guiding the aberrant" (Bazzar Ahmad n.d., 1:472). Prophet Muhammad is reported to have said: "Allah is Pleasant and loves pleasant things, Clean and loves cleanliness, Generous and loves generosity" ("Asqalani 2001, 4:254). He is also reported to have said: "Anyone offered rayhan (basil perfume) should not decline it. It is light in weight and fragrant in scent" (Sulayman 2001, 516).

10. Such as the following report on Prophet Muhammad: "Whosoever is slowed down by his deeds will not be hastened forward by his lineage" (Sulayman 1969, 3643).

11. The tradition of Prophet Muhammad illustrates this point well: "Women have certain rights over you and you have certain rights over them" (Ghazali 1997, 454). Prophet Muhammad is also reported to have said: "Treat women nicely" (Muslim 1954, 1468). In another narration, Prophet Muhamad is reported to have said: "Women are men's partners" (Sulayman 1969, 236).

12. See Bensaid and Grine $(2014,13)$. Prophet Muhammad is reported to have said: "God has left no excuse for the person who lives to be sixty or seventy years old; God has left no excuse for him; God has left no excuse for him" (Bayhaqi 1992, 3:370).

13. One may draw on a number of traditions driving much of the Muslim public ethical norms towards the elderly such as: "He is not one of us who does not show mercy to our young ones and esteem to our elderly" (Ibn Hibban 1993, 458).

14. Prophet Muhammad is reported to have said: "No Muslim is pricked with a thorn, or anything larger than that, except that a good deed will be recorded for him and a sin will be erased as a reward for that" (Muslim 1954, 2572).

15. Prophet Muhammad is reported to have said: "(Allah) will reward the one whose two dear things (that's his eyes) were taken away from him with Paradise" (Tirmidhi n.d., 2401). 
16. Prophet Muhammad is reported to have left Ibn Umm Maktum twice as his successor in Madinah to lead the prayer, though he was blind (Ahmad). Ibn Umm Maktum was a muezzin of Allah's Messenger though he was blind (Tabarani 1994, 1:6).

\section{References}

Abu Al-'Izz, A. n.d. Sharh al-'Aqidah al-Tahawiyyah (8th ed.), eds. N.M. Albani et al. Beirut: Al-Maktab al-Islami.

Abusulayman, A. 1989. Islamization of knowledge (vol. 1). Hendon: International Institute of Islamic Thought.

Albani, N.M. n.d. Silsilat al-Ahadith al-Sahihah. Riyadh: Maktabat al-Ma'arif. 1984. Sharh al-'Aqidah al-Tahawiyah, ed. 'Ali bin 'Ali ibn Abi al-'Izz. Beirut: Al-Maktab al-Islami.

Allport, G.W. 1950. The individual and his religion. New York, NY: Macmillan. 1954. The nature of prejudice. Reading, MA: Addison-Wesley. 1966. The religious context of prejudice. Journal for the Scientific Study of Religion 5(3): 447-457. https://doi.org/10.2307/1384172 1979. The nature of prejudice. Cambridge, MA: Maddison-Wesley.

Allport, G.W. and Ross, J.M. 1967. Personal religious orientation and prejudice. Journal of Personality and Social Psychology 5(4): 432-443. https://doi.org/10.1037/ h0021212

'Asqalani, H.A. 2001. Hidayat al-Ruwat ila Takhrij Ahadith Al-Masabih wal-Mishkat, ed. Ali bin Hasan al-Halabi. Dammam, Saudi Arabia: Dar Ibn al-Qayyim.

Baghawi, H.M. 1991. Sharh al-sunnah, eds. Ali M. Mu'awwadh and 'Adil A. 'Abdul Mawjud. Beirut: Dar al-Kutub al-'Ilmiyyah.

Balderson, D.C. 2014. Love. In Encyclopedia of psychology and religion (2nd ed.), ed. D.A. Leeming, 1374-1375. New York, NY: Springer. https://doi.org/10.1007/9781-4614-6086-2_394

Batson, D.C, Schoenrade, P. and Ventis, L.W. 1993. Religion and the individual: A socialpsychological perspective. Oxford: Oxford University Press.

Bayhaqi, H.A. 2003. Shu 'Ab al-Iman, ed. Hamdi D. Muhammad. Beirut: Dar al-Fikr. 1992. Al-Sunan al-Kubra. Beirut: Dar al-Ma'rifah.

Bazzar Ahmad, 'A. n.d. Al-Bahr al-Zakhkhar, ed. Mahfuz al-Rahman Zinuallah. Medina: Maktabat al-'Ulum wal-Hikam.

Bensaid, B. and Grine, F. 2014. Old age and elderly care: An Islamic perspective. Cultura: International Journal of Philosophy of Culture and Axiology 11(1): 141-163. https://doi.org/10.5840/cultura20141119

Benson, P.L. 1988. The religious development of adults. Paper presented at the Annual Convention of the Religious Research Association, Chicago, IL.

Biblehub.com. Luke 14:13. Bible hub - Online bible study suite. http://biblehub.com/ Luke/14-13.htm (accessed 23 December 2016).

Brown, R.J. 1995. Prejudice: Its social psychology. Cambridge, MA: Blackwell.

Bukhari, I.M. 1980. Al-Jami' al-Sahih, ed. Muhibb al-Din al-Khatib. Cairo: Al-Maktabah al-Salaf.

Butler, R. 1975. Why survive? Being old in America. New York: Harper \& Row. 
Conway, M., Mount, L. and Pizzamiglio, M.T. 1996. Status, community, and agency: Implications for stereotypes of gender and other groups. Journal of Personality and Social Psychology 71(1): 25-38. https://doi.org/10.1037/0022-3514.71.1.25

Dovidio, J.F., Glick, P. and Rudman, L.A. 2005. Introduction: Reflecting On the Nature of Prejudice: Fifty years after Allport. In On the nature of prejudice: Fifty years after Allport, eds. J.F. Dovidio, P. Glick and L.A. Rudman, 1-16. Gospons, India: Blackwell. https://doi.org/10.1002/9780470773963.ch1

Gaertner, S.L. and Dovidio, J.F. 1986. The aversive form of racism. In Prejudice, discrimination, and racism, eds. J.F. Dovidio and S.L. Gaertner, 61-89. San Diego, CA: Academic Press.

Ghazali, M. 1997. Fiqh al-Sirah (7th ed.), ed. Muhammad N. Albani. Damascus: Dar alQalam.

Ghorbani, N., Watson, P.J., Ghramaleki, A.F., Morris, R.J. and Hood Jr., R.W. 2002. MuslimChristian religious orientation scales: Distinctions, correlations, and cross-cultural analysis in Iran and the United States. The International Journal for the Psychology of Religion 12(2): 69-91. https://doi.org/10.1207/S15327582IJPR1202_01

Gorsuch, R.L. and McPherson, S.E. 1989. Intrinsic/extrinsic measurement: I/E-revised and single-item scales. Journal for the Scientific Study of Religion 28(3): 348-354. https://doi.org/10.2307/1386745

Haddad, Y. 2003. Gurbah as paradigm for Muslim life: A Risale-i-Nur worldview. In Islam at the Crossroads, ed. Abu-Rabi, 237-254. Albany, NY: Sunny.

Hafizi, S., Koenig, H.G. and Khalifa, D.A. 2015. Psychometric properties of the Farsi version of Hoge intrinsic religiosity scale in Muslims: A brief report. Pastoral Psychology 64: 839-845. https://doi.org/10.1007/s11089-015-0648-2

Hood Jr., R.W., Hill, P.C. and Spilka, B. 2009. The psychology of religion: An empirical approach (4th ed). New York, NY: Guilford.

Jana-Masri, A. and Priester, P.E. 2007. The development and validation of a Qur'an-based instrument to assess Islamic religiosity: The religiosity of Islam scale. Journal of Muslim Mental Health 2(2): 177-188. https://doi.org/10.1080/15564900701624436

Ibn al-Mulaqqin, 'U. 2004. Al-Badr al-Munir fi-Takhrih al-Ahadith wal-Athar al-Waqi 'ah fil-Sharh al-Kabir, ed. Mustafa A. Abdul Hayy. Saudi Arabia: Dar al-Hijrah.

Ibn Hazm, A. n.d. Al-Muhalla bil-Athar. Dar al-Jil. Cairo: Ahmad Shakir.

Ibn Hibban, M.A. 1993. Sahih Ibn Hibban, ed. Shu'yab al-Aranaut. Beirut: Muassasat alRisalah.

Ibn Kathir, I. n.d. Tafsir al-Qur'an al-Azim, eds. Muhammad al-Banna, Muhammad 'Ashour and 'Abdul 'Aziz Ghanim. Egypt: Dar al-Sha'ab.

1995. Irshad al-Faqih ila Ma'rifat Addilat al-Tanbih, ed. Bahjah Y. Abu alTayyib. Beirut: Mu'assassat al-Risalah.

Ibn Taymiyyah, A.'A. 1978. Majmu’ Fatawa Shaykh al-Islam. n.p.: n.pub.

Ismail, N.A.H., Tekke, M., Othman, N. and al-Hafiz, A.A.R. 2016. Students' Islamic personality on ibadah: A structural modeling approach. Procedia - Social and Behavioral Sciences 219(31): 755-761.https://doi.org/10.1016/j.sbspro.2016.05.073

Muhammad, S. 1993. Al-Maqasid al-Hasanah fi-Bayan Kathir min al-Ahadith alMushtahirah 'Ala al-Sunah, ed. Muhammad U. al-Khisht. Beirut: Dar al-Kutub al'Arabi. 
Muslim, A.A. 1954. Sahih Muslim, ed. Muhammad Fuad Abdulbaqi. Beirut: Dar Ihya alKutub al-'Arabiyyah.

Qaysarani, M.A. 1995. Dhakhirat al-Huffaz, ed. 'Abdurahman al-Firywai. Riyadh: Dar al-Salaf.

Pauloutzian, R. 1996. Invitation to the psychology of religion. Boston: Allyn \& Bacon.

Pettigrew, T.F. and Tropp, L.R. 2006. A meta-analytic test of intergroup contact theory. Journal of Personality and Social Psychology 90(5): 751-783. https://doi. org/10.1037/0022-3514.90.5.751

Randolph-Seng, B. 2014. Prejudice. In Encyclopedia of psychology and religion (2nd ed.), ed. D.A. Leeming, 1374-1375. New York, NY: Springer. https://doi. org/10.1007/978-1-4614-6086-2_521

Rowatt, W.C., Carpenter, T. and Haggard, M. 2014. Religion, prejudice, and intergroup relations. In religion, personality, and social behavior (1st ed.), ed. V. Saroglou, 170-192. New York: Psychology Press.

Sakhawi, M. 1993. Al-Maqasid al-Hasanah fi Bayan Kathir min al-Ahadith al-Mushtahirah 'ala Al-sinah, ed. Muhammad U. al-Khisht. Beirut: Dar al-Kutub al-'Arabi.

Schmid, K. and Hewstone, M. 2010. Combined effects of intergroup contact and multiple categorization: Consequences for intergroup attitudes in diverse social contexts. In The psychology of social and cultural diversity, ed. R.J. Crisp, 299-321. Maiden, MA: Wiley-Blackwell. https://doi.org/10.1002/9781444325447.ch13

Sulayman, S.A.D. 1969. Sunan Abi Dawud, ed. 'Izzat U al-Da'as. Beirut: Dar al-Kutub al-'Ilmiyyah.

2001. Al-Marasil, ed. 'Abdullah B. al-Zahrani. Cairo: Dar al-Sumayi'.

Tabarani, S. 1994. Al-Mujam al-Awsat lil-Tabarabi', eds. Tariq bin Awadullah and Muhsin al-Husayni. Cairo: Dar al-Haramayn.

Tekke, M., Ismail, N.A.H., Adnan, M.A.M. and Othman, N. 2015. Students' Islamic personality on amanah: A structural modeling approach. Social Sciences and Humanities 23(1): 1-10.

Tekke, M., Ismail, N.A.H., Othman, N. and Hassan, S.S. 2016. The influence of selfregard on response of belief in God and awareness of prophetic teaching. Journal of Education and Learning 10(3): 208-217. https://doi.org/10.11591/edulearn. v10i3.3664

Theiss-Morse, E. and Hibbing, J.R. 2005. Citizenship and civic engagement. Annual Review of Political Science 8(1): 227-249. https://doi.org/10.1146/annurev. polisci.8.082103.104829

Tirmidhi, M.I. n.d. Sunan al-Tirmidhi, ed. Ahmad Shakir. Beirut: Dar al-Kutub al'Ilmiyyah.

Triandis, H.C. 1961. A note on Rokeach's theory of prejudice. Journal of Abnormal and Social Psychology 62(1): 184-186. https://doi.org/10.1037/h0043114

Wahid, A. 1979. Dinamisasi dan modernisasi pesantren. Yogyakarta: Bunga Rampai Pesantren.

Whitley, B.E. and Kite, M.E. 2010. The psychology of prejudice and discrimination. Belmont, CA: Thomson Wadsworth.

Woolfolk, A.E. 2016. Educational psychology (13th ed.). Cambridge, MA: Allyn and Bacon. 